\section{Editor-in-Chief \\ Barbara McLain - (retired Prof.) \\ University of Hawaii, USA}

The Israeli Journal of Aquaculture (IJA) is an interdisciplinary journal that is dedicated to sharing new research and tested applications of aquaculture

The IJA is devoted to scholarly articles for improved aquaculture practices and related industries

The IJA is a peer-reviewed, open-access, electronic journal

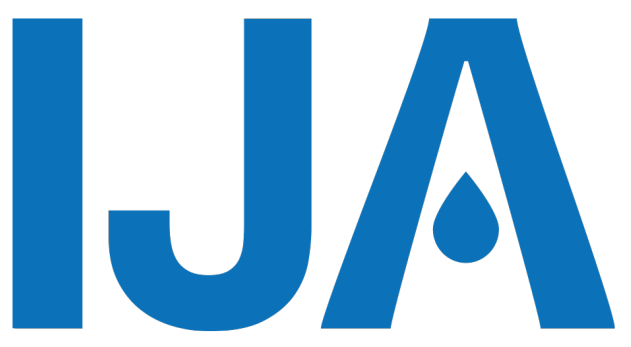

\section{The () Israeli Journal of Aquaculture}

An interdisciplinary online Open Access scientific journal

Published by the

\section{AquacultureHub}

A non-profit organization 501c3

http://www.aquaculturehub.org

in partnership with the

\section{University of Hawaii at Manoa} Library

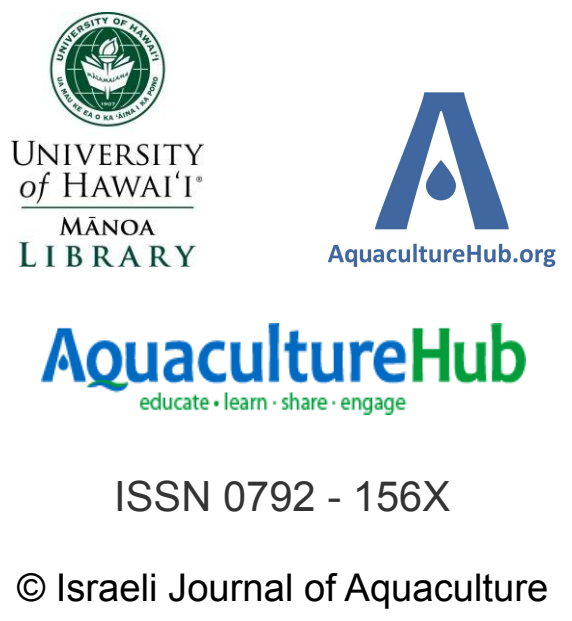




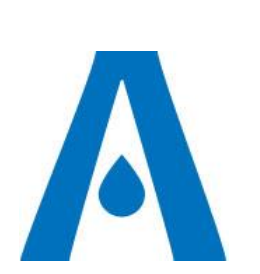

Produced by the AquacultureHub non-profit Foundation the IJA is an open-access, scientific journal, published on http://www.aquaculturehub.org/group/israelijournalofaq uaculturebamidgehija

To read papers free of charge, please register online at the above website.

Sale of $I J A$ papers is strictly forbidden.

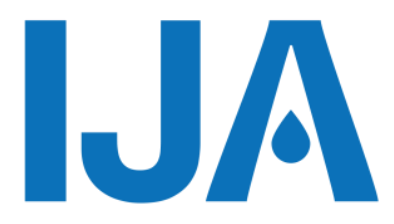

\title{
Streptococcal Infection Caused by Enterococcus casseliflavus in Cultured Meagre (Argyrosomus regius)
}

\author{
Urku C*, Timur G \\ Department of Fish Disease, Faculty of Aquatic Sciences, University of Istanbul, 34470, \\ Ordu Cad. No: 200. Laleli-Istanbul/Turkey
}

Keywords: Enterococcus casseliflavus; meagre; IFAT; PCR; streptococcal infection; 16S rRNA sequencing; slide agglutination test

\begin{abstract}
Gram Positive Streptococci (GPS) have become increasingly important fish pathogens. In this study, 170 moribund marine fish (sea bass, gilthead sea bream, meagre, sharp snout sea bream, and marine rainbow trout), obtained from 30 fish farms in the Black Sea and Aegean Sea regions of Turkey, were investigated for the presence of GPS. Streptococci were recovered from fifteen moribund young meagre (Argyrosomus regius) from an inland fish farm located in the Aegean region. The isolates were identified as Enterococcus casseliflavus using a Polymerase Chain Reaction-based (PCR) method. This result was confirmed with 16S rRNA gene sequencing and serological methods, including slide agglutination and IFAT. The diseased meagre showed unilateral or bilateral exophthalmia, loss of eyes, and hemorrhagic ulcerative skin lesions on the body surface. Histopathologically, tubular degeneration and congestion in the kidney, myopathy in the heart tissue, discharge of the white pulp in the spleen, extensive vacuolation of hepatocytes, and congestion in the liver were observed. Intraperitoneal challenge with one of the isolates in healthy European sea bass (Dicentrarchus labrax) in resulted mortalities 8 days post-injection.
\end{abstract}

* Corresponding author. Cigdem Urku; Tel: +90 2124555700/16439;

Fax: +90 2125140379; email: curku@istanbul.edu.tr 


\section{Introduction}

Outbreaks of bacterial diseases have caused great economic losses in the aquaculture industry (Austin and Austin, 2016). It is increasingly recognized that the Gram-positive cocci (GPC) are important fish pathogens (Eldar and Ghittino, 1999; Athanassopoulou and Roberts, 2004; Diler et al. 2002).

Streptococcal infections should be regarded as a complex of similar diseases, since they have been used to describe diseases caused by lactic acid bacteria, including streptococci, enterococci, and lactococci (Hawkesford, 1997; Diler et al. 2002; Austin and Austin, 2016). It has been reported that Enterococcus faecalis (Teskeredzic et al. 1993), Enterococcus sp. (Toranzo et al. 1994), Streptococcus iniae (Zlotkin et al. 1998), S. agalactiae (Evans et al. 2002), Lactococcus garvieae (Eldar and Ghittino, 1999; Diler et al. 2002; Altun et al. 2013; Ürkü and Timur, 2014) are among the main streptococcal pathogens. Among this bacterial species, the most pathogenic streptococci are known as enterococci, and they are also recognized as pathogens for both higher animals and fish (Athanassopoulou and Roberts, 2004).

In Turkey, there are no reports to date about streptococcal infections in cultured marine fish. This study describes the report of streptococcal infection in cultured marine fish in Turkey. Bacteriologic, histopathologic, molecular analyses, and pathogenicity test results demonstrated that $E$. casseliflavus caused significant mortality in the cultured meagre in earthen ponds. This paper is the first report of new streptococcal infection caused by $E$. casseliflavus in cultured meagre.

\section{Fish Sampling}

\section{Materials and Methods}

Thirty cultured marine fish farms (marine cage, inland ponds, and hatchery units), located in the Black Sea and Aegean Sea regions of Turkey were visited between October 2013 and April 2015. 170 moribund marine fish species (111 sea bass, 32 sea bream, 21 meagre, 3 sharp snout sea bream, and 3 marine rainbow trout) were sampled and examined with a range of bacteriological and histopathological methods.

\section{Bacteriology}

Bacteriological samples of liver, kidney, spleen, and blood were streaked onto Tryptic Soy Agar (TSA) containing $1,5 \% \mathrm{NaCl}$ and plates were incubated at $22-25 \mathrm{C}^{\circ}$ for 24-48 h. All isolated bacteria were identified using conventional biochemical tests to the genus level (Ludwing et al. 2009; Austin and Austin, 2016). Presumptive GPS isolates $(n=15)$ were further characterized for their biochemical properties using the API 20Strep, Rapid ID 32Strep and Vitek 2 (GPI) systems (bioMerieux) according to the manufacturer instruction except incubation temperature, which was $23 \pm 0.5^{\circ} \mathrm{C}$ (Toranzo et al. 1994).

Polymerase Chain Reaction (PCR) and 16S rRNA Sequencing

Genomic DNA was extracted using the Roche Genomic DNA Purification Kit (11796828001, Germany) according to the manufacturer's instructions. The extracted DNA from the streptococci suspected isolates was subjected to PCR with Enterococcus primers as reported by Deasy et al. (2000). Species-specific identification was carried out using Enterococcus casseliflavus specific primers $\mathrm{CA}_{1}$ and $\mathrm{CA}_{2}$ (Jackson et al. 2004). L. garvieae (R R: ATCC 43921) and Enterococcus casseliflavus (REc: ATCC 700327) were used as a negative and positive control, respectively. An approximately 1400 bp long fragment of the 16S rRNA gene was amplified using the universal bacteria primer set; primer U8F ( $5^{\prime}$ AGAGTTGATCATGGCTCAG 3') and primer 1492R (5'GGTTCACTTGTTACGACTT3') (Weisburg et al. 1991).

\section{Streptococcal Serotyping}

Recovered presumptive Enterococcus spp. were also characterized using a commercially available streptococcal serotyping kit (Healthcare, 2/763), in parallel with $\mathrm{R}_{\mathrm{Ec}}$, Enterococcus faecalis (REf: ATCC 29212) and RLg.

Immunization of Rabbit

The rabbit was immunized intravenously with $10^{9}$ cells $/ \mathrm{ml}$ of the formalin-killed $\mathrm{R}_{\mathrm{Ec}}$ and rabbit anti-E. casseliflavus and sera were obtained according to Sorensen and Larsen (1986). 


\section{Slide Agglutination Test}

Slide agglutination tests were conducted as previously described (Toranzo et al. 1987). PBS, $R_{\mathrm{Lg}}$ and $\mathrm{R}_{\mathrm{Ef}}$ performed negative control test.

Indirect Fluorescent Antibody Technique (IFAT)

The method described by Kang et al (2004) for the diagnosis of lactococcosis, was used to identify the isolates with minor modifications. $10 \mu \mathrm{l}$ test antigens were added to the well of slides. After fixation, $10 \mu \mathrm{l}$ of rabbit anti-E. casseliflavus sera diluted 1:400 in PBS was added and incubated for $30 \mathrm{~min}$ at $37 \mathrm{C}^{\circ}$. Thereafter, slides were treated with 1:80 dilution of FITC labelled with goat anti-rabbit IgG (Chemicon, AP132F) for 30 min at $37 \mathrm{C}^{\circ}$, washed with PBS three times, and stained with $0.1 \%$ Evans blue for $3-4 \mathrm{~min}$ at $37 \mathrm{C}^{\circ} .100 \mu \mathrm{l}$ closure solution was added and slides were observed under a fluorescent microscope. The same protocol was performed with $R_{E f}$ and $R_{L g}$. and PBS buffer was used as negative control.

Histopathology

Samples of tissues from visceral organs and gills were processed for histopathology by fixing in $10 \%$ buffered formalin and processed for paraffin embedding. Histological sections (4- $5 \mu \mathrm{m})$ were stained with hematoxylin and eosin (H\&E) (Culling 1963).

Pathogenicity Test

A pathogenicity test of one of the isolated strains was performed in European sea bass $(10-15 \mathrm{~g})$ by intraperitoneal injection of $0.1 \mathrm{ml}$ of bacterial culture $\left(1 \times 10^{7}\right.$ cells $\left./ \mathrm{ml}\right)$ (ten fish per dose). 10 control fish were injected with saline. Fish were maintained in seawater at $24-25^{\circ} \mathrm{C}$ with aeration for 21 days and regularly monitored (Nieto et al. 1995).

\section{Clinical and Bacteriological Findings}

\section{Results}

A range of Gram-negative bacteria, including Vibrio spp., Aeromonas spp., and Pasteurella sp. were recovered from the 155 cultured marine fish samples. Limited isolations of Grampositive bacteria including Staphylococcus spp. (30/155) and Mycobacterium spp. (Mycobacterium marinum and Mycobacterium frederiksbergense) (15/155) were isolated catalase negative, chain-forming Gram-positive cocci shaped bacteria were isolated from 15 separate moribund young meagre $(5-10 \mathrm{~g})$ obtained from an inland fish farm located in the Aegean region. This disease outbreak occurred in August, following transportation of the cultured meagre juveniles from the hatchery to earthen ponds. The water temperature was $25-26 \mathrm{C}^{\circ}$ and salinity was $30 \%$ at the time of sampling. Externally moribund meagre samples showed unilateral or bilateral exophthalmia, or loss of eyes (Fig. 1a) and necrotic lesions around the eyes (Fig. 1b), loss of scales, hemorrhagic ulcerative skin lesions on the body surface (Fig. 1C); internally accumulation of a clear liquid in the abdominal cavity and intestine, splenomegaly, pale liver and liquefaction of the head kidney (Fig. 1d). 


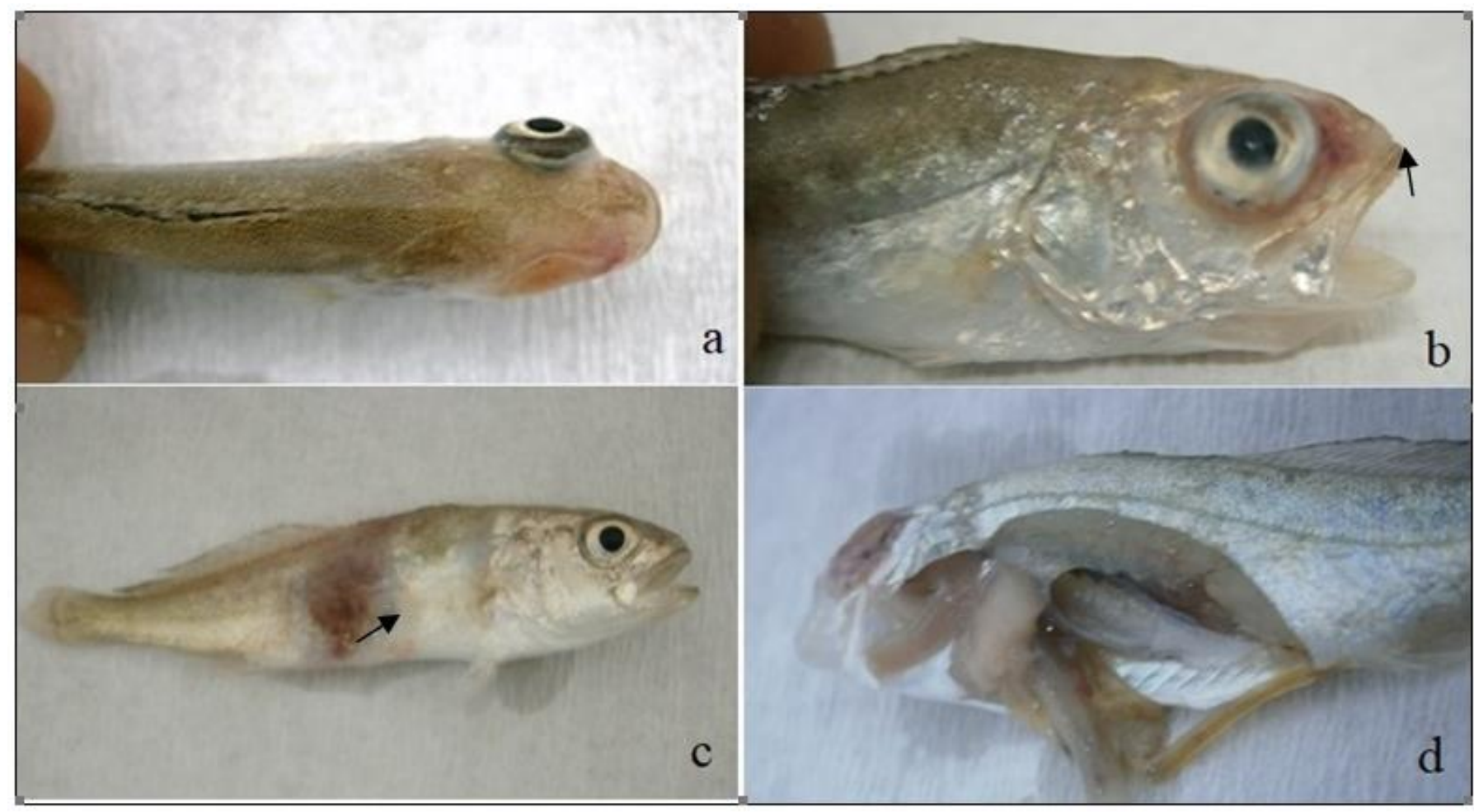

Fig. 1 Unilateral exophthalmia, loss of eyes (a), and necrotic lesions around the eyes (arrowed) (b), loss of scales and hemorrhagic ulcerative skin lesion (arrowed) on the body surface (c), accumulation of a clear liquid in the swelled intestine, pale liver, liquefaction of the head kidney (d).

After incubation of the bacteriological inoculations from the visceral organs and blood of moribund meagre, the isolated bacteria produced small, round and yellowpigmented colonies onto TSA. They were non-motile, Gram positive, cocci shaped, pairs or short chains and fermentative, sensitive to vancomycin, alpha-hemolytic, and produced PYRase enzyme. Therefore, fifteen streptococci suspected isolates were identified as Enterococcus sp. These isolates were not identified to the species level with two of the commercial identification systems used (Rapid ID 32Strep/76377517351 and API 20Strep/7357770), although they were identified with Vitek $2(93 \%)$ as E. casseliflavus.

\section{PCR Amplification and 16S rRNA Sequencing Findings}

Using the genus specific PCR, we obtained a single733 bp length PCR product. Further, PCR products of the expected size (288 bp) were also obtained for REc and isolates using the PCR assay targeting the superoxide dismutase gene $(\operatorname{sod} A)$. Thus, these isolates were identified as $E$. casseliflavus. $16 \mathrm{~S}$ rRNA sequencing (99\%) confirmed this result. The sequences obtained in this study are deposited in GenBankinder accession numbers MH376356, 376403.

\section{Streptococcal Serotyping Findings}

The $R_{E C}, R_{E f}$ and fifteen meagre isolates were all characterized as group $D$ streptococci using the streptococcal serotyping kit (Healthcare, 2/763).

\section{Slide Agglutination Test}

All the meagre isolates strongly reacted with the rabbit anti-E. casseliflavus sera. $R_{E f}$ produced little reaction, which was only observed under the light microscope whereas RLg did not react.

\section{Indirect Fluorescent Antibody Technique}

All tested meagre isolates were also strongly positive (showed bright green fluorescence) by the IFAT and this serologic diagnostic test did not yield any false positive results with $R_{E c}$ and $R_{L g}$.

\section{Histopathological Findings}

Histopathologically, tubular degeneration and congestion in the kidney (Fig. 2a), myopathy in the heart tissue (Fig. 2b), discharge of the white pulp in the spleen (Fig. 2c), extensive vacuolation of hepatocytes and congestion in the liver (Fig. 2d), sloughing of the propria mucosa and columnar mucosal epithelium into the lumen, hemorrhages, and 
hyperplasia of the secondary lamella and sloughing of the necrotic gill epithelium cells; and congestion in the brain were observed.

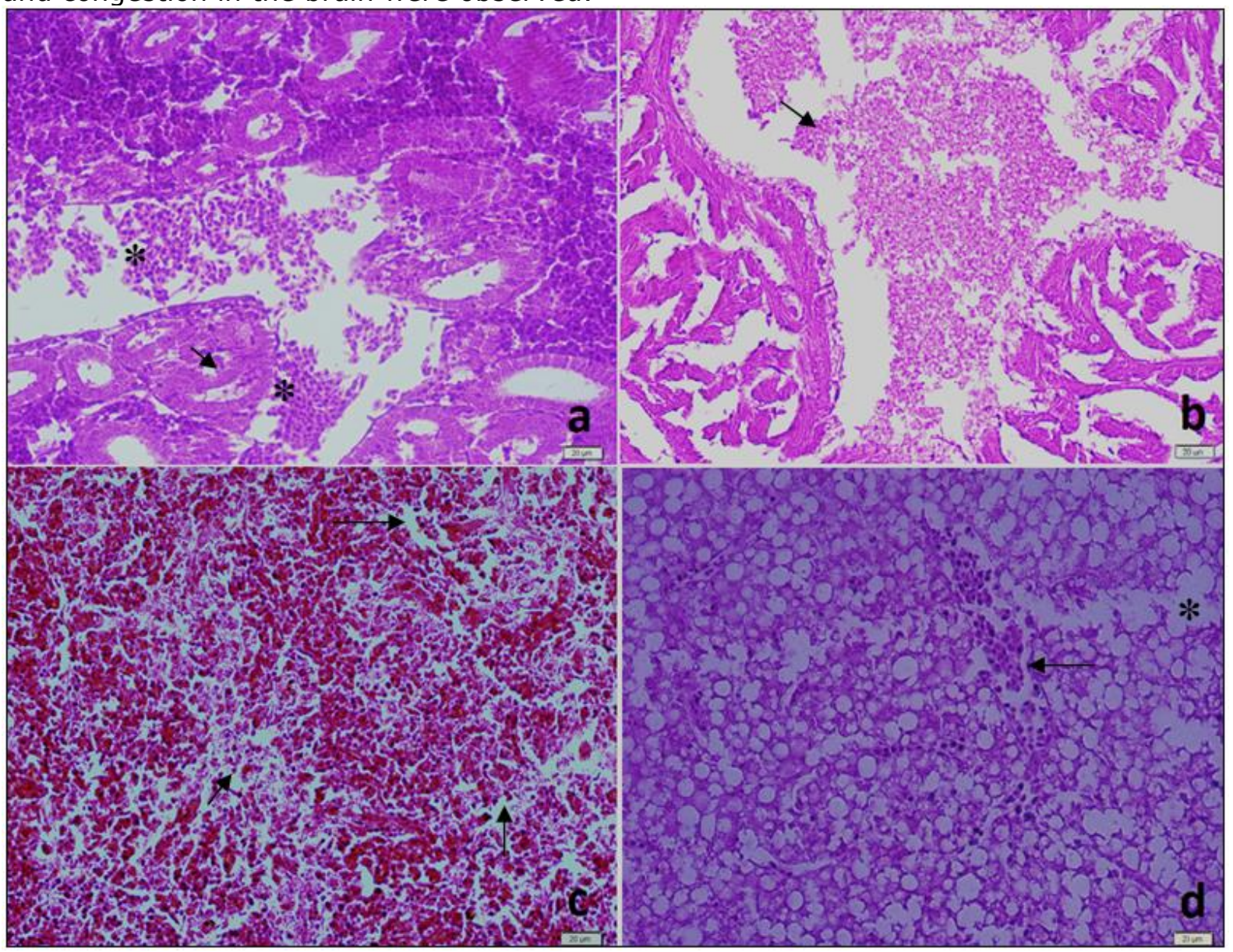

Fig. 2 Tubular degeneration (arrowed) and congestion (*) in the kidney (a); myopathy in the heart tissue (arrowed) (b); discharge of the white pulp in the spleen (arrowed) (c); vacuolation of hepatocytes (*) and congestion in the liver (arrowed) (d) (H\&E)

\section{Pathogenicity Test Findings}

E. casseliflavus isolate (MH376356) caused mortalities when injected intraperitoneally into juvenile meagre. The first fish mortalities were observed in experimental fish group 8 days post- injection. Moribund sea bass showed similar clinical signs in the naturally infected meagre. The inoculated bacteria were re-isolated from visceral organs of all dead fish.

\section{Discussion}

The streptococcal agents causing streptococcal infection in marine cultured fish have been reported from different countries (Toranzo et al. 1994; Zlotkin et al. 1998; Dilet et al. 2002; Evans et al. 2002; El-Aamri et al. 2010) However, there are no reports about streptococcal agents isolated from cultured marine fish species in Turkey.

Enterococci are recognized as pathogens for both higher animals and fish (Athanassopoulou and Roberts, 2004). E. faecalis has been described as a possible pathogen of brown bullhead (Teskeredzic et al. 1993). Sebastiao et al. (2015) described the association of E. casseliflavus in tilapia (Oreochromis niloticus), carp (Cyprinus carpio) and cachara (Pseudoplatystoma reticulatum) but did not note any associated clinical or pathological signs. In this study, E. casseliflavus were isolated and identified from the cultured young meagre with cumulative mortality of approximately $30 \%$.

The gross pathology observed in moribund meagre bear similarities to that in farmed brown bullhead (Amiurus nebulosus) infected with $E$. faecalis such as deep 
ulcerative skin lesions on the body surface and accumulation of a clear liquid in the swelled intestine (Teskeredzic et al. 1993). In addition to these findings, typical external signs such as uni or bilateral exophthalmia, the presence of hemorrhages in the periorbital and intraocular area and loss of eyes also were observed in the moribund meagre as reported in the turbot (Romalde et al. 1996), tilapia (Amal et al. 2011), rainbow trout (Diler et al. 2002).

Hemorrhages and hyperplasia in the seconder gill filaments, congestion or hyperemia in the brain tissue, hemorrhages in the body muscles and sloughing of the necrotic longitudinal and circular muscles of the intestinal wall, propria mucosa and columnar mucosal epithelium into the intestinal lumen were observed in the infected meagre as in turbot infected with Enterococcus sp. (Toranzo et al. 1994; Nieto et al. 1995). In addition, in these findings we observed tubular degeneration and congestion in the kidney, myopathy in the heart tissue, discharge of the white pulp in the spleen, extensive vacuolation of hepatocytes, and congestion in the liver.

In the present study, according to Gram staining, presence of PYRase enzyme, growth at $\mathrm{pH} 9.6$ and $6.5 \% \mathrm{NaCl}$, sensitive to vancomycin, isolated bacteria were identified as Enterococcus sp. and presumptively $E$. casseliflavus for yellow pigment production (Ludwing et al. 2009). Our isolates were not identified by Rapid ID 32Strep and Api 20Strep. Jackson et al. (2004), reported insufficiency of these rapid identification kits for the identification of Enterococcus spp. isolated from environment, agricultural or other animal sources. However, in the present study, E. casseliflavus was successfully identified by Vitek-2 system. In addition to this positive result, our isolates were identified as $E$. casseliflavus using E. casseliflavus-specific PCR as described by Jackson et al. (2004). This result confirmed $16 \mathrm{~S}$ rRNA gene sequencing using serological methods (IFAT and slide agglutination test).

$R_{E f}$ reacted with rabbit anti-E. casseliflavus sera as described by Toranzo et al. (1995). But the cross-reactions did not occur among the $R_{E f}$ and $R_{L g}$ using IFAT. This result showed that IFAT is more sensitive than slide agglutination test for identification of these pathogenic bacteria.

In conclusion, E. casseliflavus was associated with diseased juvenile meagre from inland-based facility and the associated clinical symptoms were reproduced when a recovered isolate was injected intraperitoneally. The gross pathological findings of the moribund cultured meagre and the pathogenicity test indicated that $E$. casseliflavus is a potentially new streptococcal pathogen of marine fish.

\section{Acknowledgements}

Istanbul University Research Projects Fund supported this study (Project number: 35111/ BEK-2017-26596). The Ethics Committee approved this study for Animal Experiments of the University of Istanbul 2013/69.

\section{References}

Altun S., Onuk E.E., Ciftci A., Büyükekiz A.G., M. Duman, 2013. Phenotypic, genotypic characterisation and antimicrobial susceptibility determination of Lactococcus garvieae strains. Kafkas Univ Vet Fak Derg, 19, 375-381.

Amal M.N.A. and M. Zamri-Saad, 2011. Streptococcosis in tilapia (Oreochromis niloticus): a review. J Agr Sci, 34: 195-206.

Athanassopoulou F., and R.J. Roberts, 2004. Streptococcal infections of farmed fish. J Hellenic Vet Med Soc, 55: 136-144.

Austin B. and D.A. Austin, 2016. Bacterial Fish Pathogens, Diseases of Farmed and Wild Fish, 6th ed., Springer, Dordrecht.

Baeck G.W., Kim J.H., Gomez D.K. and S.C. Park, 2006. Isolation and characterization of Streptococcus sp. from diseased flounder (Paralichthys olivaceus) in Jeju Island. J Vet Sci, 1: 53-58.

Culling C.F.A., 1963. Handbook of histopatological tecniques (İncluding museum tecnique). Second education, Butterworth and Co, 25-97.

Deasy B.M., Rea M.C., Fitzgerald G.F., Cogan T.M. and T.P. Beresford, 2000. A rapid PCR based method to distinguish between Lactococcus and Enterococcus. Syst Appl Microbiol, 23: 510-522. 
Diler O., Altun S., Adiloglu A., Kubilay A. and B. Isıklı, 2002. First occurrence of streptococcosis affecting farmed rainbow trout in Turkey. Bull Eur Assoc Fish Pathol, 22: 21-26.

El-Aamri F., Padilla D., Acosta F., Caballero M.J., Roo J., Bravo J. and F. Real, 2010. First report of Streptococcus iniae in red porgy (Pagrus pagrus, L.). J Fish Dis, 33: 901-905.

Eldar A. and C. Ghittino, 1999. Lactococcus garvieae and Streptococcus iniae infections in rainbow trout Oncorhynchus mykiss: similar, but different diseases. Dis Aquat Organ, 36: 227-231.

Evans J.J., Klesius P.H., Gilbert P.M., Shoemaker C.A., Al-Sarawi M.A., Landsberg J., Duremdez R., Al-Marzouk A. and S. Al-Zenki, 2002. Characterization of $\beta$ hemolytic Group B Streptococcus agalactiae in cultured seabream, Sparus auratus L., and wild mullet, Liza klunzingeri in Kuwait. J Fish Dis, 9: 505-513.

Hawkesford T, 1997. Microbiological studies of Lactococcus garviae in fish. PhD thesis, University of Tasmania.

Jackson C.R., Fedorka-Cray P.J. and J.B. Barretti, 2004. Use of a genus-and speciesspecific multiplex PCR for identification of enterococci. J Clin Microbiol, 42: 3558-3565.

Kang S., Shin G., Shin Y., Kim Y., Yang H., Lee E., Huh N., Ju O. and T. Jung, 2004. Experimental evaluation of pathogenicity of Lactococcus garvieae in black rockfish (Sebastes schlegeli). J Vet Sci, 5: 387-390.

Ludwing, W., Schileifer, K.H. and W.B. Whitman, 2009. Bergey's Manual of Systematic Bacteriology. In Whitman WB (Ed): The Firmicutes Family Enterococcaceae. Springer Inc., NewYork, 594-607.

Nho S.W., Shin G.W., Park S.B., Jang H.B., Cha I.S., Ha M.A., Kim Y.R., Park Y.K., Dalvi R.S., Kang B.J., Joh S.J. and T.S. Jung, 2009. Phenotypic characteristics of Streptococcus iniae and Streptococcus parauberis isolated from olivefounder (Paralichthys olivaceus). FEMS Microbiol Let, 293: 20-27.

Nieto J.M., Devesa S., Quiroga I. and A.E. Toranzo, 1995. Pathology of Enterococcus sp. infection in farmed turbot, Scophthalmus maximus L. J Fish Dis, 18: 21-30.

Romalde J.L., Magarinos B., Nunez S., Barja J.L. and A.E. Toranzo, 1996. Host range susceptibility of Enterococcus sp. strains isolated from diseased turbot: possible routes of infection. Appl Environ Microbiol, 62: 607-611.

Sebastiao F.A., Furlan L.R., Hashimoto D.T. and F. Pilarski, 2015. Identification of bacterial fish pathogens in Brazil by direct colony PCR and 16S rRNA gene sequencing. Adv Appl Microbiol, 5: 409-419.

Sorensen U.B.S. and J.L. Larsen, 1986. Serotyping of Vibrio anguillarum. Appl Environ Microbiol, 51: 593-597.

Teskeredzic E., Grahek D., Malnar L., Teskeredzic Z., M. Hacmanjek, 1993. Bakterijska bolest americkog somica (Amiurus nebulosus L.). Ribarstvo, 48: 5-11.

Toranzo A.E., Baya A., Roberson B., Barja J., Grimes D. and F. Hetrick, 1987. Specificity of slide agglutination test for detecting bacterial fish pathogen. Aquaculture, 61: 81-97.

Toranzo A.E., Cutrin J.M., Nunez S., Romalde J.L. and J.L. Barja, 1995. Antigenic characterization of Enterococcus strains pathogenic for turbot and their relationship with other Gram-positive bacteria. Dis Aquat Organ, 21: 187-191.

Toranzo A.E., Devesa S., Heinen P., Riaza A., Nunez S. and J.L. Barja, 1994.Streptococcosis in cultured turbot caused by an Enterococcus-like bacterium. Bull Eur Assoc Fish Pathol, 14: 19-23.

Ürkü C.. and G. Timur, 2014. Comparative study of detection methods for Lactococcus garvieae in experimentally infected rainbow trout (Oncorhynchus mykiss, W.). Bamidgeh, IJA_66.2014.1025, 1-10.

Weisburg W.G., Barns S.M., Pelletier D.A. and D.J. Lane, 1991. 16 S ribosomal RNA amplification for phylogenetic study. J Bacteriol, 173: 697-703, 1991.

Zlotkin A., Hershko H. and A. Eldar, 1998. Possible transmission of Streptococcus iniae from wild fish to cultured marine fish. Appl Environ Microbiol, 64: 4065-4067. 